\title{
WHAT TEACHERS DO, OBSERVE, AND FEEL IN PEDAGOGICAL PRACTICE THROUGH THE USE OF DIGITAL RESOURCES
}

\author{
Paula Quadros-Flores ${ }^{1}$, António Flores ${ }^{2}$, Altina Ramos ${ }^{3}$ \\ ${ }^{1}$ Polytechnic Institute of Porto, High School of Education (PORTUGAL) \\ ${ }^{2}$ Polytechnic Institute of Porto, Higher Institute of Engineering of Porto (PORTUGAL) \\ ${ }^{3}$ University of Minho (PORTUGAL)
}

\begin{abstract}
In the context of the initial teacher training, namely in the Supervised Pedagogical Practice, it is imperative that the future teacher has the opportunity to develop skills that dignify him in the $21 \mathrm{st}$ century, but also that he is encouraged to (re)create the new educational paradigm, finding propulsive impulses of dynamic spheres of innovation and entrepreneurship, responsibility and opportunity for growth. In this sense, and knowing that Information and Communication Technologies (ICT) have an enormous potential for renewal of the educational paradigm and teaching professionalism (Quadros Flores, 2016), the study aims to know educational experiences with ICT: what they do, how they do and what teachers do feel and what impacts do they observe.
\end{abstract}

In this context, we analysed seventeen lesson plans that applied digital resources carried out in the primary school by future teachers attending the Master's Degrees in "Pre-School Education and Teaching of the First Cycle of Basic Education" and Master's Degree in "First Cycle of the Basic Education and Mathematics and Natural Sciences of the Second Cycle of Basic Education". Three activities were selected with the criterion being innovative, useful, usable and transferable to other contexts. In order to understand what they observe and feel during the implementation of the practices, we opted for a qualitative methodology of a case study. Data were collected from a questionnaire with two open questions applied to seventeen future teachers carrying out the Supervised Educational Practice (internship) in the primary schools. For data analysis, we used content analysis. The results show that, when teachers use technological resources, they adopt a constructivist methodology and that, during the class, they observe impacts on the student, on the learning process and on the school results. The analysis of the answers also reveals effects in three dimensions, essential in the process of teaching and learning: in the motivation, as a means by which the learning is realized, in the understanding that in turn it gives meaning to the learning and the satisfaction, as the result of the motivation that facilitated the comprehension and that, therefore, improves the results of the students and the professional accomplishment of the teacher. When questioned about what they felt in managing an ICT class, they looked at the process of teaching and learning, regarding the student and regarding themselves (teacher). They show, therefore, that the feeling experienced by the teacher in the pedagogical act has a direct relationship with the teacher, as a professional (capacity of methodological, strategic and resource selection, creative capacity in the construction of an environment favourable to the process of teaching to learn), as a person (sensations experienced, responsibility, commitment), but also with the impact on the student. Thus, it is concluded that the success of technology integration depends mainly on the teacher, his technical training in the domain of the tool and his professional training in methodological domain, as well as other skills, such as creativity, resilience, entrepreneurship and leadership.

Keywords: Innovation, Initial teacher education, ICT, Methodological renewal.

\section{INTRODUCTION}

Hargreaves [1] announced that the rules of the world were changing and Castells [2] confirmed the change that Information and Communication Technologies (ICT) implemented in society. The scientific, social, and political echo disseminate change, and we feel a dominating force caused by these "new" technologies that effectively change living, communication and the relationship patterns that (re)structure interests, the meanings we attach to things that we share, the social nature, which require reflection to align the past with the present in the direction of the future. The change requires consistent and aligned references and the initial formation of teachers assumes a privileged place because it stimulates the construction of the formation itself, through observation, planning, action and reflection, in a continuous cycle of analysis, reflection and problematization that stimulates knowledge, 
know how to do, know how to transform being and being in education. On the other hand, this change happens in a context that is also constantly changing, and this has implications for the future teacher currently in the process of formation, who wants to be a professional with scientific, didactic and experimental knowledge, capable of making decisions with autonomy and freedom regarding the construction of their professional teaching identity. In this dynamic of personal and collective action, the product of relations and meeting of decisions, in the dialectic of self and of the other, it grows an identity character that aligns the future teacher with his peers and contexts of formation, with the elements of the past and the expectations of the future, which determine the self-knowledge of others, the personal and the social, in a context of autonomy of thought, values and behaviours.

The initial formation of teachers propitiates the principle of metamorphosis from student to teacher and gives meaning and shape to the future teaching. As Bolivar points out [3], we are what we do in a set of areas: knowledge and skills possessed, satisfaction and identification with work, socialization, status granted, being that in this construction of representations, the stage represents a space of construction of ways of being and of being in the profession, a place of personal, professional and social growth, where the interaction of the person, the professional and the culture of a society interact in a whole and are growing throughout life. In this evolutionary and (re)interpretation process, the future teacher is redefined and rebuilt into an individual and collaborative dynamism, comprising the social sphere, its demands and responses to old and new problems.

This scenario reveals the importance of a training that includes digital competences, so that the future teacher can benefit from the educational possibilities offered by ICTs, as a professional who learns and teaches how to learn. The school was developed and programmed in the era in which information was not easily accessible to all. Now, a new step is being taken beyond that of the Gutenberg galaxy, to the Internet galaxy that affected the environment and the student and especially the informational medium that have been drawn by a methodology sustained in the printed paper book. In fact, nowadays the digital world opens a new informational scenario accessible to all, regardless of the time and space that revolutionizes habits and cultures, interests and motivations, for which the effectiveness of the old methodologies to solve new problems that the current technologies emerge is questioned. It urges a new articulation of knowledge and skills, of digital resources that facilitate new methodologies that promote the organization and management of knowledge according to the mission of the school. Also, other attitudes and competences that generate new opportunities for the use of ICT with students, in an inclusive way, avoiding the digital division, new looks in the educational horizon that exceed the spatial and temporal limits of the school, communication and sharing. According to the National Institute of Educational Technology and Teacher Training [5], the teaching competencies should involve five major areas: a) and b) information and information literacy; c) communication and collaboration; d) creation of digital content; e) security and problem solving, so it is essential to develop instrumental, pedagogical and didactic, investigative, organizational, communication and social interaction, information search and management skills and competencies for the preparation of presentations and didactic materials. The same document highlights the need to develop digital skills in the education system in order to learn how to integrate the correct use of ICT in the classroom, stressing the need for "safe and critical use of information and communication technologies at work, leisure time and communication" as recommended by the European Parliament and the Council [6]. It falls within the framework of the digital competences of the citizen [7], with reflections on the profile of the student that sees a young person who is autonomous, responsible and aware of the world around him and who draws up cultural, scientific and technological literacy skills, analyse, question, evaluate, select and decide on situation; develop critical and creative thinking, the ability to work collaboratively and communicate; developing capacity to adapt to change and uncertainty in a changing world [8]. In this sense, in the student, it is indispensable to develop transversal and multidimensional competences that involve the articulation of knowledge, attitudes and values that stimulate behaviours of knowledge management, communication and an active attitude in society and not only the acquisition of curricular contents. Faced with this change, the teacher lives moments of anguish, but also of stimulating challenges in the profession. What they see and feel in ICT practices can help us understanding the integration process of ICT in education.

\section{METHODOLOGY}

In order to understand what teachers perceive and feel during the implementation of ICT practices, we opted for a qualitative approach, the exploratory study. This study "applies to realities not yet studied and unknown to increase the familiarity of the researcher with an environment, fact or phenomenon" [9], (p. 190). To get acquainted with the phenomenon, having a small data sample, to 
emerge from the curiosity of the researcher, are the reasons that, for this author, justify this exploratory study.

To collect data, an open answer questionnaire was prepared for seventeen future teachers who attended the Master's Degree in Pre-School Education and Teaching of the First Cycle of Basic Education (1st CEB) and Master's Degree in First Cycle and Basic Education and Mathematics and Natural Sciences of the Second Cycle of Basic Education. These students were carrying out Supervised Educational Practice (internship) in primary schools. Two of the questions in this questionnaire are analysed in this article. Seventeen lesson plans that included digital resources were also analysed. In order to understand what they do and how they do, when integrating digital resources into educational practices, three activities were selected as innovative, useful, usable and transferable to other contexts.

The analysis was made by a descriptive and interpretative methodology.

\section{INNOVATIVE EDUCATIONAL EXPERIENCES WITH ICT}

To better understand the results of this study, we present initially what students do and how they do, when using digital devices in their pedagogical practices. Three of these practices were selected. We will then analyse and discuss the results concerning what they observe and feel regarding their innovative experiences.

The inclusion of ICT in education is an opportunity for the transformation of pedagogical practice and re-creation of an educational paradigm that responds and satisfies the requirements of the $21^{\text {st }}$ century. Its social impact shows that the professions for which we have been training our students may no longer exist in the future, but other professions are re-created day by day in a market that is seen to be innovative in technologically new products and processes and that is presented as being challenging in the drive to change, creativity and entrepreneurship. In this sense, the initial teacher training represents an opportunity to recreate the educational scenario by training future teachers who coexist naturally with digital technology in education, drawing from it all the potential to develop new methodologies that foster improvement, not only in curricular scope, but also in the development of competences, as referred to in the 21st century student profile [8]. It is also intended that they develop capacities, behaviours, attitudes and competences in order to be resilient, autonomous, flexible in the different contexts, creative in solutions, proactive in interactions and innovative in strategies and vision of education.

Next, three activities with different digital resources are presented:

+ Practice 1 - Contextualization: due to poor school results and a lacklustre educational environment, the school loses students and needs to recreate its presence in the locality;

Methodology: Project-based learning;

Objective: to improve students' results and satisfaction by motivating them in the learning process;

Curricular articulation: study of the environment, Portuguese, Mathematics, ICT;

Motivation: use of Voki by students and caregivers;

Development: students learned how to use the program at school; at home, studied the curricular contents of the various curricular areas and selected one or more subjects to present to their classmates at school, creating Avatars interacting in the classroom (every Friday). The custodians could also construct, being presented in the classroom by their students.

+ Practice 2 - Contextualization: second year students need to improve reading:

Methodology: reflection-based learning;

Objective: perform a storytelling to stimulate the reading and understanding of a poem;

Curricular articulation: Portuguese, Music Expression, ICT;

Motivation: record the reading of the students by creating a Storytelling;

Development: in class, students observe and listen to Storytelling about a poem, analyse it and reflect critically on the readings performed (self and straight evaluation). For a better understanding they carry out, in an online digital tool, a map of concepts. Re-create the poem and do a collective reading, 
copy it by building an online book that they share in a class blog. They reinforce reading in rap, using a new digital tool.

+ Practice 3 - Contextualization: first year students receive a letter from a school requesting an itinerary to visit the city of Porto;

Methodology: problem-based learning;

Theme: visit to the city of Porto;

Objective: understand the itinerary design;

Curricular articulation: study of the environment, Portuguese, Mathematics, ICT;

Motivation: Google maps, Scratch;

Development: the students investigate in Google, with the support of the teacher, the most relevant monuments of the city of Porto. They have built an itinerary on Google Maps and visit it to verify its correctness and cultural relevance. They later construct an itinerary based on coordinates in Scratch.

Impact: students and teachers felt pleasure in class.

In view of the above, what have future teachers observed and felt? What impacts did they observe?

\section{ANALYSIS AND DISCUSSION OF RESULTS}

\section{1 "What do I feel when I use ICT in educational practice": the opinion of future teachers}

Innovation is not innocuous in the distribution of resources and opportunities, but in internship modality, all students find solutions by themselves to overcome obstacles, regardless of the internship context. Creativity, entrepreneurship, a flexible and adaptive attitude is an imperative that makes the difference. The internship context is appropriate and welcomes the use of ICT, but depending on the strategy, students use their own resources in the classroom. In general, there are interactive whiteboards or projectors, the Internet, Wireless in some schools, and one computer per classroom, which often requires the use of the library or ICT room for some classes or other solutions found by future teachers. It should be noted that this does not seem to be the only obstacle to innovation, as they also refer to its lack of technical expertise in the face of the requirement of some digital devices.

As Area says [11] what is learned and how it is taught are human decisions that do not depend on the technology involved, but on the conceptions and pedagogical competences of the teacher in making appropriate decisions to create and generate learning situations. Thus, in pedagogical practice, future teachers experience the teaching world and collect observed information, sensations and representations of what it is to be a teacher of the 1st CEB. The close observation of what is done, how it is done, why it is done, allows us to become aware of the values that emerge from the educational action, the representation of the professional self and the changes that take place within it.

In this sense, responding to the questionnaire applied, namely "What do I feel when I use ICT, as a trainee teacher", it is noted that the word "more" stands out in the written speech by the frequency with which it is referred to in the various responses, namely "ICT added value" in educational practices, immediately defining a positive feeling and satisfaction with the lesson planned and implemented, justified in the various adjectives in the discourse referring to the student, to the teacher and to the classes: "more satisfied", "safer and more confident", "more secure and satisfied", "more involved", "more comfortable", "more satisfaction", "more satisfaction and commitment", "much more motivated students", "more capable", "more meaningful classes", "more spontaneous". The analysis of the answers to the question led us to understand that there are three fundamental dimensions in which teachers focus when they define their feelings regarding the integration of ICT in pedagogical practices:

1 The process of teaching and learning - "tools that have come and change teaching"; "I can teach in a more meaningfully way"; "ICTs promote more innovative, more dynamic classes, stimulating student involvement"; "more perceptible, simplifying the pedagogical practice"; stimulate the "construction of more meaningful learning"; "the activities become more enjoyable not only for students, but also for professionals"; foster "change in teaching"; "brings the 
classroom closer to the reality of the students"; "greater self-involvement in what I am planning"; "they came to change the teaching".

In methodological terms they refer that "we focus the class on the students and not so much on our speech"; "becomes more dynamic"; "it helps me to guide the class in a more controlled way"; "I like to use ICT in the classroom for the diversity of activities that can motivate students to develop meaningful learning spontaneously"; "the activities become more enjoyable, not only for the students, but for the teacher"; "make classes more innovative, more dynamic"; "they are an asset... they allow a wide range of pedagogically rich activities"; "I consider classes to become more meaningful"; they also emphasize the resource: "fundamental for the construction of a meaningful learning"; "to teach more meaningfully"; "as an element of motivation for children to perform tasks with pleasure".

It is also worth mentioning the objectives of the respondents: "children are more motivated and that is what I want"; "they are a very strong motivating element... actively involving them in the learning process and providing meaningful activities... challenge... brings difficulties, but promotes many learning", "children are much more motivated and it is what I intend to captivate students to learn".

2 The impact on the student - "more motivated students", "arouses great interest in students", "I see more motivated and interested students in my class", "I can motivate students more... bring education closer to their interests", "produce meaningful learning for all students", "motivation element for children and perform tasks with greater pleasure", "are more interested in the content developed", "children are more motivated".

3 The impact on the teacher - "I feel that I am going to meet what it is to be a teacher of the 21st century"; "Despite some difficulties in not completely mastering resources, I can motivate children to learn by exploring autonomously", "I can make them better able to live in a technological world and of now", "I show interest and pleasure in exploring... more satisfaction when I get articulate a certain technology with several areas of knowledge", "it is not always easy to use them by the specific conditions of the classrooms, which causes some constraints", "it is crucial that I master ICT", "time spent in the construction and manipulation of resources, it was worth it", "I was worried about not only completely mastering, but in the meantime I was acquiring skills", "I feel safe... and confident..., "ICT will be the basis of my future practices", " satisfaction and commitment. "

This result shows that in the educational act there is an alignment of the methodological strategy and the educational resources with the objectives of the class and that these dimensions are fundamental for educational success. Thus, the objectives are mainly focused on student motivation through meaningful learning in a satisfaction environment. In this context, ICTs are fundamental in responding to the demands of educational practice, as they foster change in the ways of teaching and learning, as they make classes more innovative, dynamic, engaging and perceptible, capable of making learning meaningful and spontaneous, with focus on the student, highlighting their interests and reality. In this process, they provide an environment of pleasure and opportunities that foster the satisfaction of the student and the teacher, and in this professional also improves his commitment in the construction of the lesson plan and the pleasure of using this type of resources. In relation to the student's impact, the verbs "involve", "awaken", "motivate", "captivate", "prepare", "approach", "produce", "accomplish", "interest" innovative and dynamic education they refer to and their positive impact on the student. However, this scenario is a positive challenge for the future teachers, because it is verified that despite the difficulties of technical mastery and to find solutions for the lack of technological resources in the classroom and also the time spent in the preparation of the educational practice, "well worth it", well reinforced in the "I can" motivate and train citizens of the future, in "I feel, I meet", "I feel safe... and confident", but also "more satisfaction and commitment".

\section{2 "What impact do I observe": in the students, in the learning process and in school results}

The analysis of the respondents' answers allowed us to construct the following cloud (Fig. 1), which shows that the integration of digital and interactive classroom devices has a positive impact on the student, in particular motivating impulses that stimulate attitude (curiosity, attention, understanding), but above all the action / behaviour (commitment, participation, involvement). In addition, it has an impact on the results because it "satisfies", meaning that they cause a sense of pleasure to be sufficient to achieve the students' goals. By stimulating the positive attitude, it activates the student's 
interest in learning, provoking a desire for involvement and a sense of satisfaction, which shows that ICT is a didactic tool and a promoter of success in education.

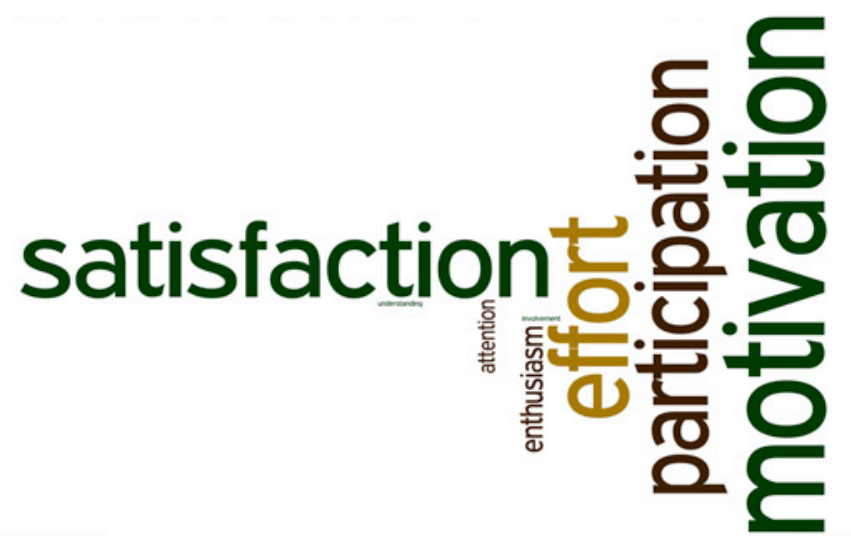

Fig. 1 - Impact of ICT on students.

In addition, these are not experienced in the same way in all contexts ("not everyone dominates ICT, which makes someone annoyed, because it is not something that they do control"; "they do not have any type of constraint in the use of ICT"; "they participate actively and relevant") and that "they sometimes learn without realizing that they are producing knowledge", so that the teacher's challenge to the educational context in order to promote the change in the classroom and the tendency for a natural and instant learning, or better "Learnability" [12].

Regarding the impact of ICT in the learning teaching process (Figure 2), respondents design a renewed methodology, based on constructivist principles that make learning more accessible, immediate and meaningful to the student, have an impact on student behaviour, more participative and committed, and show a simplified process and facilitator of the acquisition and construction of knowledge stimulating the development of other skills and new experiences, centering the student in the process in order to make it more autonomous.

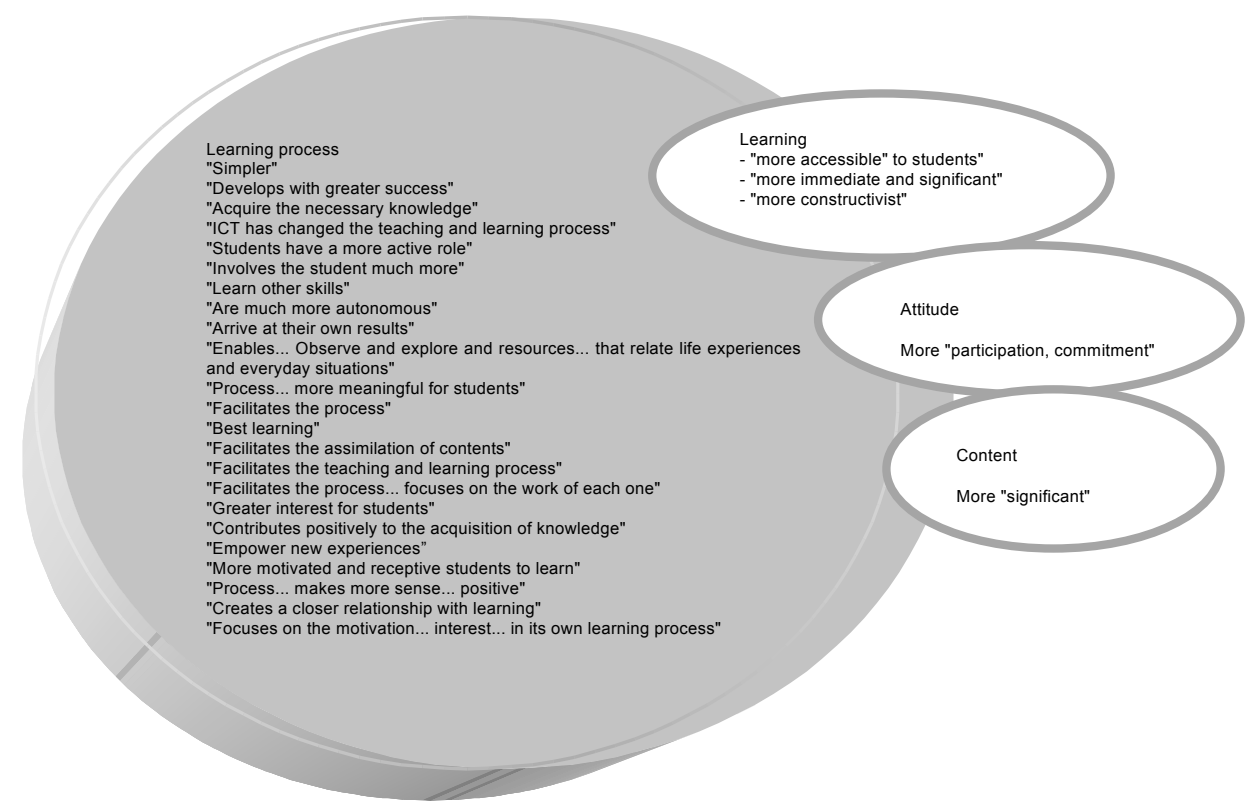

Fig. 2 - Impact of ICT in the learning process.

Regarding the impact on the results, we have the following answers: "tendency to improve", "better", "allows... good results", "more positive", "slight improvement in working sheets", "significant improvement"... "I think that the results should improve", "students who demonstrate difficulties have surprised the quarterly records", "more easily understand and interlink contents", "positively influences results", "improve", "more positive results, more satisfactory", "better and more quickly achieved". It is observed that the results depend on the educational practice in general, that motivates the student or 
not, some of which clearly state the improvements registered, but others did not feel significant differences. However, in general it seems to us that the results are positive, since in addition to improving the results, they make the process of building and acquiring knowledge faster, they facilitate the understanding and articulation of curricular contents. In addition, they reinforce that students' motivation, involvement, and commitment arouse interest and curiosity, contributing to school success, and that those attitudes "depend on how they are used with students and how receptive they are to the addressed content".

\section{CONCLUSION}

Education is currently facing challenges through the inclusion of powerful digital devices in a wide range of dimensions, in particular in the teaching and learning process, and a reflection on the way in which ICTs are included in educational practices, the voice of future teachers who observe and feel their effects directly.

Thus, it seems to us that the way teachers define their feelings enhances the construction of their professional selves influenced by the dynamics of teaching action that reflect an immense concern about the student and the way in which his learning takes place, insofar as these dimensions have an effect on their commitment, satisfaction and professional achievement. This feeling of the pedagogical act has a direct relation with the capacity of methodological, strategic and resource selection, that is to say, it is the responsibility of the teacher, reason why teacher satisfaction or dissatisfaction depends to a great extent on its capacity to promote learning environments promoters of satisfaction in the process of teaching to learn that satisfies and motivates the student in and for learning. In this sense, we would say that teachers who use ICT are not only concerned with the students' school results, but above all with the process of information acquisition and knowledge construction that should be engaging, engaging and enjoyable, since it influences the state of student spirit in the face of learning and, consequently, of the teacher in the construction of an innovative and dynamic plan that meet the interests of the students. It was verified that dynamic and interactive methodologies were found, stimulating growth opportunities, building knowledge in formal and informal environments, building relationships that stimulate dialogue and sharing, security and personal and social well-being. Despite this, respondents warn of the need for more consistent education in ICT use. It was also verified that the future teachers understood that the motivation is a high value element to achieve the fundamental learning in the formative process of the student, as well as it is a challenge for the teacher who has to find the strength that breaks the state of equilibrium by creating a need that causes action, as Maslow points out [13].

This scenario presents a challenge for the initial teacher training that it has to be more concerned with training creative, resilient, flexible, entrepreneurial, empathic, autonomous professionals with digital competences and other scientific, didactic, cultural and emerging knowledge of educational practice, and able to mobilize them in the know-how, reflect and transform of the different curricular areas of the 1st CEB, in short, in their daily pedagogical practice.

\section{REFERENCES}

[1] A. Hargreaves, Os professores em tempos de mudança. Alfragide: McGraw-Hill, 1998.

[2] M. Castells, A era da informação: economia, sociedade e cultura - o poder da identidade. A sociedade em rede. Lisboa: Fundação Caloustre Gulbenkian, 2005.

[3] A. Bolívar, La identidade profesional del professorado de secundaria: crisis y reconstrucción. Málaga: ediciones Aljibe, 2006.

[4] M. Enguita and S. Cupeiro, La Larga y Compleja Marcha del CLIP al CLIC: escuela y professorado ante el nuevo entorno digital. Madrid: Fundación Telefónica, 2016.

[5] INTEF (20seventeen). Marco Común de Competencias Digital Docente. Madrid: INTEF. Retrieved from http://educalab.es/documents/10180/12809/MarcoComunCompeDigiDoceV2.pdf

[6] Parlamento Europeu e do Conselho, "Recomendação do Parlamento Europeu e do Conselho sobre as competências essenciais para a aprendizagem ao longo da vida", Jornal Oficial da União Europeia, 2006. Retrieved from Journal http://eur-lex.europa.eu/legalcontent/PT/TXT/?uri=celex:32006H0962 
[7] Riina Vuorikari, Yves Punie, Stephanie Carretero and Lieve Van den Brande. DigComp 2.0: The Digital Competence Framework for Citizens. Update Phase 1: The Conceptual Reference Model. Luxembourg: Publication Office of the European Union, 2016). Retrieved from https://ec.europa.eu/jrc/en/publication/eur-scientific-and-technical-research-reports/digcomp-20digital-competence-framework-citizens-update-phase-1-conceptual-reference-model

[8] Gomes et al. O Perfil dos alunos para o Séx XXI. G. Oliveira Martins (Coord.). Lisboa: Ministério da Educação, 20seventeen. Retrieved from https://dge.mec.pt/sites/default/files/Noticias_Imagens/perfil_do_aluno.pdf

[9] M. A Marconi and E. M Lakatos. Fundamentos da Metodologia Científica. São Paulo: Atlas, 2007.

[10] J. A. Cabero, "Replanteando la tecnología educativa," Comunicar, no. 21, pp. 23-30, 2003. Retrieved from http://www.redalyc.org/articulo.oa?id=15802104

[11] M. Area, "Ser docente en la escuela digital," Profesional - Magisterio, Suplemento 22, pp. 1516, 2016.

[12] A. Marina, "Learnability, la palabra del futuro," El confidencial. 25.04.20seventeen. Retrieved from http://www.elconfidencial.com/alma-corazon-vida/educacion/20seventeen-0425/learnability-palabra-futuro_1372167/

[13] A. Maslow, "A theory of human motivation". Psychological Review, no. 50, pp. 96-370, 1943. 